\title{
ON THE ACTION OF DIPHTHERIA TOXINE ON THE SPINAL STICHOCHROME CELLS. ${ }^{1}$
}

\author{
By H. RaINY, F.R.C.P.Ed., F.R.S.E. \\ From the Laboratory of the Royal College of Physicians, Edinburgh. \\ (Plate XVII.)

\section{INTRODUCTORY.}

THE following paper contains the record of a series of experiments which were undertaken with the view of determining whether the paralysis which is known to follow poisoning by various toxic substances of bacterial origin, and especially that which results from the action of the bacillus of diphtheria, is associated with alterations in the motor cells in the anterior cornua of the spinal cord; and, if such alterations were found to exist, of determining their nature and the relation which they hold to the changes found in the motor nerves.

At the time when the research was commenced (1894) the prevalent opinion, in this country at all events, was that diphtheritic paralysis was a form of peripheral neuritis. This is, however, manifestly open to objections, and a study of the cases recorded by various authors suggested to me that at least in many instances one had to deal with a central and not with a peripheral lesion. Of course, where the paralysis only attacks the structures in immediate proximity to the seat of the disease, and occurs during or just after it, the most probable explanation is that the phenomena result from the direct action of the absorbed toxine; but, on the other hand, distant parts of the body (the lower limbs for instance) are often affected some time after the disappearance of the local process, and here one is compelled to seek a different explanation for the symptoms.

The research which I have thus been led to conduct is still in many respects incomplete, but I have thought it best to record the results which $I$ have up to the present obtained, leaving my further observations to a subsequent paper.

In the reports that follow I shall assume that the reader has a general acquaintance with the recent literature of nerve cell anatomy and pathology, of which a valuable summary has been given by Ford

1 Part of a thesis submitted for the degree of M.D., University of Edinburgh, April 1899. 
Robertson, ${ }^{1}$ and I shall therefore only preface the account of my own experiments by a short abstract, in chronological order, of the principal papers which have been published on the action of the poison of diphtheria on the nervous system. ${ }^{2}$

In 1862 Charcot and Vulpian described degenerative changes in some fibres of the palatine nerves. In $1864 \mathrm{Weber}$, in two cases of post-diphtheritic paralysis, was unable to find any changes in the brain or spinal cord. In 1867 Buhl, in one case, found hæmorrhages in the brain and swelling with infiltration of the anterior and posterior cornua of the spinal cord. In $1868 \mathrm{Clos}$ found in one case changes in the nerves similar to those produced by section. In 1869 Lorain and Lepine described changes analogous to those observed by Clos. In $1870 \mathrm{R}$. Maier, in a post-mortem examination on a child of six years old, who died of diphtheritic paralysis, confirmed the observations of Buhl, especially with regard to the hæmorrhages, and considered that these produced pressure on the nerve fibres and cells. In 1871 Oertel found capillary hæmorrhages of the cerebral and spinal dura mater, and of the sheaths of the peripheral nerves. He also noted infiltration of nuclei and granulations in the anterior cornua. In 1872 Leyden observed peripheral and central lesions,the latter he attributed to neuritis migrans ascending to the central nervous system. In the same year Bailly expressed the opinion that diphtheritic paralysis might be due to a primary lesion, sometimes situated in the central nervous system, sometimes in the nerves, and sometimes in the muscles. In this year also Liouville noted slight degenerative changes in the phrenic nerves. In 1875 Roger and Lamaschino, as the result of post-mortem examination of four cases, recorded alterations in the nerves, and particularly in the anterior nerve roots. In 1876 Pierret described a case where he found disseminated plaques of spinal meningitis, as well as perineuritis in the neighbouring nerve roots. In this instance, however, as also in those of Déjerine and Barth (1880), the cases were not purely diphtheritic, but probably were suffering from an intercurrent purulent meningitis. In 1876 Vulpian, in two or three cases, observed modifications in the anterior cornual cells, which he described as being more globular than usual. He also noted that their contents were unusually homogeneous,-almost' concealing the nucleus, -and thought that possibly the processes were unusually fragile. In 1877 Sanné, as the result of observations on several cases, failed to find any constant lesion. In 1878 an extremely important paper was published by Déjerine. Besides changes in the nerves, he recorded that the anterior cornual cells were globular, were deficient in processes, that their nuclei and nucleoli had become indistinct, and that some cells had entirely perished. He also noted lesions of the anterior roots corresponding to the paralysed nerves. These lesions he considered constant. They seemed to vary in degree with the duration of the paralysis, they never affected the posterior roots, and they seemed to be secondary to changes in the grey matter of the spine. In 1879 Schech described slight degenerative changes in the vagus and recurrens. In 1880 Landouzy propounded the view that vascular changes might be primary ones. In the same year Quinquand observed lesions analogous to those described by

1 Erain, London, 1899, vol. xxii. p. 203.

2 To prevent breaking of the text, references to the papers cited have been relcgated to a Bibliographical Appendix. In the compilation of the Bibliography I am largely indebted to Meyer and Crocq. The former, in his "Anatomische Untersuchungen uber diphtheritische Lähmung," Virchow's Archiv, 1881, Bd. Ixxxv. S. 181, has supplied valuable references to the literature up to that date; the latter, in a small treatise entitled "Recherches expérimentales sur les altérations du système nerveux dans les paralysis diphtbéritiques," published in 1896, supplements Meyer's work and brings it up to date, besides giving short abstracts of many of the papers referred to. 
Déjerine. The grey matter of the lumbar region was the seat of marked hyperæmia, and numerous cells were involved. Sainclair also, in 1880 , directed attention to the presence of inflammation in the nerve sheaths, in the vessel sheaths, and in the lymph spaces of the cord; and suggested that the paralysis might be due to "meningo-lymphite." In 1881 Gaucher contended that changes only occurred in the anterior roots, and in the same year Abercrombie declared himself unable to corroborate Dejerine's observations, having found only a very slight diminution of the cells of the anterior cornua. In 1881 appeared the important paper of Paul Meyer, which has already been referred to. His conclusions, based on a very typical clinical case, were that the diphtheritic poison acted on various points of the nervous system-equally in his case, on the peripheral nerves and spinal cord. In 1883 Kidd found congestion, increase of connective tissue and atrophy of the anterior cornual cells-the atrophy being most marked in the dorsal region. In 1884 Samné concluded that the spinal lesions were primary ones, and the changes in the nerves were consecutive to them. Mendel, in 1885, found no change in the cells of a child who died of diphtheritic paralysis. In 1888 Bristowe noted a normal condition of the nerve cells, a degeneration of the third cranial nerve, and a hyperæmia with small hæmorrhages near the base of the brain. PyeSmith, in the second edition of Fagge's "Principles and Practice of Medicine," notes the divided state of opinion, but does not commit himself to any definite view. In 1889 Fuchs drew attention to the close resemblance of postdiphtheritic and post-influenzal ocular paralysis. In the same year Eustace Smith, in the second edition of his "Disease in Children," notes the probability of nerve cells being primarily or at least early affected. In 1890 Babinski states that in diphtheritic paralysis one finds a periaxial neuritis, at the same time noting that the peripheral origin of diphtheritic neuritis is very dubious. In 1892 Gowers, in the second edition of his "Diseases of the Yervous System," says in one place, "Diphtheria may cause acute changes in the nerve cells and nerve roots," and, in another place, "Diphtheritic neuritis is not wholly peripheral." In the same year MclBride pronounced diphtheritic paralysis to be due to polyneuritis, and Osler was of opinion that the primary change was a toxic neuritis. Also, in the same year, Déjerine modified his former view, and expressed his concurrence with Leyden's view. Arnleim also adhered to this opinion. In 1892 Preisz recorded observations on two cases of death from diphtheritic paralysis. In the first case he noted atrophy of the anterior cornual cells, hæmorrhages in the grey matter of the spinal cord, and changes in the peripheral nerves. In the second case, in addition to these facts, he records degeneration of the column of Goll in the cervical cord.

In 1893 Gay recorded a case of somewhat abnormal symptoms, where post. diphtheritic allochiria supervened. In the post-mortem on this case, marked degeneration was found in the columns of Goll. Stcherbak in the same year observed marked changes in the nerves of animals which had received injections of diphtheritic poison. In 1894 Vincent recorded the case of a patient, æt. 24 years, who died on the fourteenth day of his illness from diphtheritic cardiac paralysis. The medulla, vagus, and sympathetic nerves were normal, but a serious inflammation of the plexus cardiacus was found, consisting in destruction of the myelin sheath and inflammation of the axis cylinder. The changes in the heart muscle were deemed inadequate to lead to the fatal issue.

Bikeles (1894) contributed a paper describing changes which he, in association with Prof. Kolisko, observed in a very typical and extremely wellmarked case of post-diphtheritic paralysis in a middle-aged man. The nerves, which were examined by Marchi's method as well as by the commoner procedures, exhibited absolutely no alteration from the normal. The spinal cord, stained with hæmatoxylin and carmine, likewise presented no great alterations, and he was unable to detect any abnormality in the motor cells. Marchi's method, however, as applied to the cord, demonstrated a very characteristic 
degeneration of the posterior roots where they enter the grey substance of the posterior cornua, and these changes he very reasonably suggests may account for the frequent ataxic symptoms which one finds clinically associated with cases of post-diphtheritic paralysis. Enriquez and Hallion, as a result of the experimental injection of diphtheritic toxine under the skin of animals, observed very marked changes in the spinal cord. Those on which they laid chief emphasis were marked increase of vascularity-especially in the grey substance, where numerous foci of hæmorrhage were observed; patches of myelitis were also noted. In 1895 Hochhaus found neither in the central nervous system nor in the peripheral nerves any trace of pathological change in a case which came under his observation. Vidal and Bezançon observed changes in the posterior columns of the spinal cord after the use of streptococcus toxine, in the case of experimental investigations conducted in 1895 . The importance of this observation is manifest, as many of the cases in which changes in the white matter of the spinal cord have been recorded were clinical cases where the possibility of a mixed infection must always be borne in mind. In this year, Crocq, jun., published his first communication on the subject, but as in the following year he published a very much more full account of his work, the statement of his conclusions will be reserved until that is noticed. In 1896 Pernici and Scagliosi reported an examination of the central nervous system. In the brain many of the cells were normal; others were somewhat markedly implicated, and by Golgi's method were found to present varicose atrophy. The changes in the spinal cord were indefinite, many of the cells appeared smaller than normal-a condition which the present writer has also observed-and their protoplasm was granular. The nuclei are reported as having often presented a shrunken aspect, whilst some of the cells were in a state of extremely advanced disintegration. In the same year Manicatide published a paper in which he collated nineteen cases of postdiphtheritic paralysis. He divided the cases into four groups-(1) cases where the lesion was purely muscular, with no nerve implication; (2) cases of polyneuritis; (3) lesions of the spinal cord which were either localised in the grey substance leading to atrophy of muscle, or involved the white matter of the cord in a manner such as is found in locomotor ataxia, or multiple sclerosis ; (4) central paralysis, chiefly resulting from changes in the circulation. He notes in his paper that Ceni established an experimental postdiphtheritic primary encephalitis, but no clinical cases have been recorded of this condition. Courmont, Doyon, and Paviot conducted experiments on the action of the diphtheritic toxine on frogs kept in incubators, on dogs, and on a horse. Peripheral lesions alone were observed. The neuritis was associated with paralysis and atrophy of muscle. The functions of the sensory nerves seemed unimpaired. On one occasion only was the presence of myositis established. They further noted that the diphtheritic poison required, in coldblooded animals, that the temperature should be raised to a point above that which they usually possess-in the case of frogs, $38^{\circ} \mathrm{C}$.

Turning to English authors we find that in the same year (1896) Kanthack, writing in Clifford Allbutt's "System of Medicine," expresses the opinion that the primary lesions consist in a parenchymatous degeneration of the nerves, and also of degenerative changes in the muscle. In support of his opinion he quotes Déjerine, Gombault, Meyer, and Sidney Martin-the latter of whom especially lays stress on the changes of nerve and muscle. Gee, in the same volume, also seems inclined to account for the symptoms which one meets with in post-diphtheritic paralysis, by assuming the existence of multiple neuritis. The same view is expressed by Rotch in his treatise on "Hygiene and Medical Treatment of Children."

In 1896 Crocq, jun., summed up the results of all his observations in a short monograph on diphtheritic paralysis. His conclusions will be given at some length as representing the general state of opinion in the year when his 
results were published. He says: "In the spinal cord the diphtheritic poison provokes very marked alterations of the grey matter; the cells become swollen, they stain badly, their nuclei and processes disappear; the neuroglia and ependyma proliferate, the nerve cells atrophy or may disappear altogether and be replaced by sclerosed tissue. The white substance is but rarely affected. Thus, myelitis generally progresses slowly. In some cases, however, it may be rapidly evolved and may end in softening.

"As regards the nerves, the diphtheritic poison produces a degeneration which is first manifested by irregularity in the contour of the nerve fibres, by the segmentation of the myelin, and by the hypertrophy or multiplication of the nuclei. Presently the axis cylinder breaks into segments, the myelin aggregates into clroplets, the protoplasm increases in amount. Eventually the axis cylinder disappears, the protoplasm becomes still more abundant, and the nuclei still more numerous, until at last the myelin is entirely absorbed. This degeneration is most distinctly visible at the anterior roots, whilst the posterior roots remain almost normal. With regard to the medulla, the diphtheritic poison only produces some swelling of the cells at its lower part-the middle and upper parts remaining normal. The cranial nerves are not affected by the diphtheritic poison. The poison produces in the rabbit a primary myelitis and secondary peripheral neuritis. Diphtheritic paralysis is distinctly different in man and in the rabbit. In the former it generally begins with involvement of the palate and throat, with the rabbit by weakness of the hind-limbs. In man, diphtheria seems to produce two different kinds of paralysis, in which the one remains localised in the nouth, nose, eyes, larynx, and pharynx, whilst the other is generalised and may affect the whole body, commencing with the lower limbs. It is reasonable to suppose that the former is due to a primary peripheral neuritis, whilst the latter depends in man, as in the rabbit, on a primary myelitis with secondary neuritis."

In 1897 papers appeared by Sharp, Katz, and Murawjeff, as well as others of less importance, which will be recorded in the bibliography. Sharp applied diphtheritic toxine to the isolated heart. He observed that the beats were at first intensified, the systole soon became weakened, whilst diastole was lengthened, arrest finally occurring with the heart fully dilated. He considers this result to follow from the action of the toxine on the heart muscle, but beyond the statement of this experiment he offers no proof for his thesis. Katz examined the spinal cord of three children who had died of diphtheritic paralysis at ages of from 5 to 6 years. Golgi's and other methods were employed. In all three cases the anterior cornual cells were found partly necrotic and partly exhibiting fatty degeneration. In the peripheral nerves, destruction of the axis cylinder was observed, and special note was made of the fact that the phrenic nerves were implicated in this process. The diaphragm is described as having been fatty. Murawjeff made a series of examinations of the spinal cord of guinea-pigs which died in from one to three weeks after the injection of cultures of diphtheria. He found in the anterior cornual cells all degrees of chromatolysis, nuclear changes, and vacuolation. Many fibres in the peripheral nerve trunks were also degenerated, but this change he considered secondary to that of the cells. In the same year he also investigated the action of diphtheritic antitoxin, and came to the conclusion that it causes similar changes in the cells and nerves, and that the intensity of its action depended directly on the dosage. He found further that, if the toxin and antitoxin were given simultaneously, changes only occurred when the toxin was in excess, so that some of it remained free. He also noted that if the toxin were administered some time before the antitoxin, its effect on the cord varied with the interval between the administration of the poison and of the remedy. From this series of observations he concludes-(1) that the antitoxin is a valuable remedy ; (2) that it must be used early ; $(3)$ that it is not an indifierent substance, and is therefore best used in small and repeated doses. 
In 1898 a very considerable addition has been made to our knowledge of post-diphtheritic paralysis. Thomas, reviewing the subject and basing his conclusions on the observations which he was able to make on twenty-five fatal cases states-(1) that marked parenchymatous degeneration of the peripheral nerves is an ordinary condition, and that it is occasionally associated with hyperæmia, hæmorrhages, and interstitial changes; $(2)$ that in the brain and spinal cord acute diffuse parenchymatous degeneration occurs in the nerve fibres, whilst little or no change was found by him in the nerve cells; (3) that degenerative conditions are present in the heart muscle and other muscles of the body; (4) that sometimes one observes hyperæmia, infiltration, and hæmorrhage in the brain and spinal cord, but that these conditions are rarely severe enough to leave permanent effects; (5) that sudden death, during the disease or convalescence, results from the action of the toxin on the nervous apparatus of the heart. Murawjeff followed up his former observations by experiments on the action of the streptococcus. He injected under the skin or into the peritoneum of a guinea-pig, 0.2 to 2.0 c.c. of such virulence that $0 \cdot 1$ killed a rabbit. This dose was repeated for five or seven days-the only manifest result being that the guinea-pig became thin. After four to seven weeks it was killed by chloroform, and the post-mortem was made within two hours after death. The spinal cord and nerves were examined by his own formol-methylene method, and by Marchi's method. The cells showed no great change. The posterior columns of the spinal cord were very markedly altered in the dorso-lumbar region. The posterior nerve roots were also degenerated. A combination of streptococcus and diphtheritic toxine produced the joint effects of both. Zeigler, in the ninth edition of his "Lehrbuch der Pathologie," states that diphtheria may cause spinal degeneration affecting the white matter, and he cites the analogous conditions which Tuczek and others have demonstrated in poisoning by ergot, and in pellagra. Donaggio, whose paper seems to be based on some joint work which he performed with Vasale, expresses the opinion that the nerve fibres are primarily affected, whilst the cells are not specially referred to. Babes has observed chromatolysis, vacuolation, loss of nucleus and nuclcolus, vascular changes, and increase of round cells. Enriquez and Hallion have recently made some experimental researches on the action of diphtheritic poison on the circulation and respiration. They conclude that the toxine paralyses the cardio-inhibitory centre, whilst in advanced stages the accelerans is stimulated. When the blood pressure is low, vasomotor paralysis and weakness of the heart muscle occur, the irritability of the heart is also reduced. They think that the respiratory centre is also implicated. At the meeting of the British Medical Association last summer, Professor Woodhend introduced a discussion on post-diphtherial paralysis. He gave statistics of 7832 cases of certified diphtheria. Of these cases, 5068 had diphtheritic bacilli in the throat; 1362 suffered from paralysis. Of these cases, 1096 had been treated with antitoxine. In a smaller group, where the nature of the paralysis was carefully inquired into, primary paralysis of the palate was recorded in 185 out of 494 cases. The eye muscles were primarily affected in 197; the muscles other than those of the eye in ten cases, the heart in 102 cases. The palatal cases occurred mostly between the fifth and fifteenth, the ocular between the fourth and the seventeenth; the ten muscular cases between the tenth and fourteenth; the cardiac cases mostly between the fifth and tenth; but a few cases occur as early as the second day; one as late as the fifty-ninth. And in reviewing these statistics he says: "It is evident then that in the human subject these paralyses occur at a comparatively early date, although in numerous cases they come on at very much later stages; and one cannot help thinking that we have evidence of the primary affection of the nerve cells, or of a direct action of the poison on the muscular tissue, in the fact that cardiac paralysis occurs relatively at so much earlier a period than other forms of paralysis." Further on in the paper he 
states that he has examined two cords from experimental animals treated with full doses of toxine, and that in one case the chromatolysis and vacuolation of the cells was fairly distinctly marked, whilst in the other there was no perceptible deviation from the normal. In the discussion that followed this paper, Dr. Mott stated that his opinion was that the poison acted on the whole neuron, especially upon the terminal arborisations of the dendron and the end plates. Professor Baginsky of Berlin announced that his assistant Dr. Katz had examined the brain, spinal cord, and peripheral nerves of cases of postdiphtheritic paralysis, and had found advanced degenerative changes in all parts of the nervous system, both nerve cells and nerve fibres.

Judson Bury, in his article on "Multiple Neuritis," $b$ appears on the whole to pronounce in favour of his former view that the condition is primarily a peripheral one.

\section{EXPERIMENTAL.}

It will be seen from the foregoing account that even now there is considerable variety of opinion as to the pathological changes in the nervous system which are attributable to the toxine of diphtheria; and when this research was commenced, about five years ago, reliable information was still more scarce.

The following experiments have as their aim the determination of the changes, if any, which occur in the motor cells of the anterior cornua as a result of the action of the toxine and the antitoxine of diphtheria upon them, and incidentally of any other alterations which under their influence might occur in the spinal cord.

It was from the first obvious that the problem which presented itself did not necessarily involve the securing of a picture of the state of the cells of the cord as they exist during life-which, indeed, it is quite impossible to obtain. The aim was rather to determine, by the use of methods whose application would lead to constant end-products in the case of a living cell, first, the result of such a method on the healthy cell, paying particular attention to the amount of variation which exists within normal limits; and, secondly, the comparion of these results with the appearances exhibited by diseased cells similarly treated. This principle has been insisted upon by Nissl, who describes the result in either case as the "nerve-cell equivalent" of the corresponding condition. At the same time, one is bound to consider that, other things being equal, the process which least alters the constitution or, at all events, the structure of the cell will best fulfil the requirements of the case.

In pursuance of this object a considerable number of nethods were tried, some of which were found to be unsatisfactory and were soon abandoned, whilst others seemed to meet the requirements of the case fairly well. Although even amongst the latter group one or two methods were distinctly superior to the others, and were normally 1 "Multiple Neuritis," Allbutt's "System of Medicine," 1899, vol, vi. 
employed, reliance has not been placed exclusively upon them, the results yielded by the different procedures being used to check the conclusions which the standard ones seemed to suggest.

The following critique of the more important cytological methods employed may be of service to other workers:-

A. Fixation.-The importance of as perfect fixation as possible, effected as soon as practicable after death, is now recognised by all cytologists. With the view of determining the best process for the particular end in view-the fixation of the spinal stichochromes-the following were tried:-

(1) Mann's method of fixation, by injection of the fixation fluid into the aorta. (2) Alcohol, as advised by Nissl. (3) Formalin. (4) Formalin and mercuric chloride. (5) Mercuric chloride. (6) Hermann's fixative. (7) Platinic chloride.

Mann's method, independently of the exact composition of the fixative fluid, proved unsatisfactory on three grounds-first, because during the necessary manipulation the spinal cord was dependent and therefore tended to become congested; secondly, even where the nerve elements were fairly well fixed it was impossible to draw any conclusions regarding the ante-mortem condition of the vessels, which were often dilated by the pressure of the injection fluid ; thirdly, whilst the brain was found well fixed in almost every instance, it was practically impossible to secure uniform fixation of the spinal cord, as blood, or the saline solution which was used to drive the former from the vessels, was seldom wholly got rid of. It therefore became necessary to abandon the method and to fix the structures after a preliminary dissection. (2) Alcohol, as recommended by Nissl, was tried, but, owing to the frequent occurrence of distinct shrinkage, was dismissed as unsatisfactory. (3) Formalin, in strengths of from 5 to 10 per cent., was also tried, but was not wholly satisfactory; and, so far as I can judge, after its use the staining tended to be less precise than that which was obtained by the use of mercuric chloride. (4) Ewing has recently recommended the employment of a mixture of formalin with mercuric chloride, and his figures show that in his hands the method was for the most part successful. The writer has also used it with some success, owing to the penetrative power of the formalin; at the same time, the advantage which it can offer over simple formalin fixation is but slight, as the mercuric chloride is very quickly decomposed and precipitated from the solution. (5) I was therefore led to employ as the standard medium of fixation a saturated solution of mercuric chloride in normal saline solution. (6) Occasionally, in order to check the results obtained by this, I employed Hermann's fixative mixture, which contains 1 per cent. platinic chloride, fifteen parts; glacial acetic acid, one part; and 2 per cent. osmic acid, four parts. This fixative I found extremely reliable, the chief objection being that the outer portions of the specimen tend to become blackened. Nissl's bodies, after its employment, seemed rather smaller and more finely granular than when mercuric chloride was used. (7) On some occasions I also made use of a solution of platinic chloride. I found that its general effect was not unlike that of corrosive sublimate, but the subsequent staining was less precise.

B. Embedding and cutting.-After fixation the specimens were very thoroughly washed in running water, and carried with great care through a series of graded alcohols and chloroform, after which they were embedded in paraffin. ${ }^{1}$ Sections were cut of various thicknesses, from two to eight teeth of the Rocker microtome. The thinner sections are specially valuable in the determination of detail, but present a somewhat more variable appearance than those of greater thickness. After the sections were cut, they were floated

I If the slcohols are not sufficiently graded, or if the specimen is too rapidly dehydrated, either in mass or after staining, misleading shrinkage of the cells is certain to occur. 
out on water, after Gulland's method; the very thin sections generally require colder water than those which are less delicate. When arranged on the slide, the latter is left for from twelve to twenty-four hours in an inculator whose temperature is well below that of the melting point of the paraffin; thereafter the paraffin is melted by the application of further heat, and the slide dropped into a tube of xylol, which should be frequently renewed. The mercuric chloride is thoroughly washed out of the tissues by free supplies of alcohol containing a trace of iodine, and the sections are then ready for staining.

C. Staining.--The chief stains used belong to the aniline group-(1) One of the best proved to be toluidin-blue, which I found extremely precise in its results and comparatively easy to work with, whilst it seemed fully as permanent as any of the others. The specimen, as a rule, was stained for about ten minutes in per cent. watery solution; it was then washed in water, decolorised in alcohol - this process being controlled by the use of the microscope-cleared in xylol, and mounted in Canada balsam. (2) Thioninblue was also used, but was much less precise in its staining qualities. (3) Unna's polychrome methylene-blue, which gives a most exquisite differential stain for the various structures of the spinal cord, often proved disappointingly evanescent, although fresh specimens of the stain were repeatedly obtained from Grubler; whilst the different samples were by no means uniform in their action. Bismarck-brown was occasionally employed, but possessed no advantages over the stains mentioned. (4) A stain named "Kernschwarz," although giving less brilliant pictures than toluidin-blue or methylene-blue, is fairly permanent, and would probably prove better for photographic purposes than either of the former. It is, however, more diffuse in its action. (5) M. Heidenhain's iron hæmatoxylin, either alone or in combination with saffranin, as recommended by Buihler, ${ }^{1}$ was useful in determining some of the finer structural conditions in the nerve cells. (6) One of the best methods was a modification of Held's methylene-blue and erythrosin double stain. ${ }^{2}$ I employed the methylene-blue before the erythrosin instead of after it, as recommended in the original paper, because a mixture of these two stains is apt to produce a granular precipitate which is insoluble in methyleneblue, but redissolves in erythrosin solution. The following are the details of the process as I have latterly employed it.

The sections, fixed to the slide in the usual mamer, are covered with a fluid prepared immediately before use by mixing equal parts of a solution of methylene-blue in distilled water $(0.375$ per cent.) and of 5 per cent. watery solution of acetone. This is carefully warmed until all odour of acetone has disappeared, it is then allowed to cool, and the sections are washed in water. It is thereafter stained for five or ten seconds in a solution containing $1 \mathrm{grm}$. of erythrosin in 150 c.c. of distilled water, to which a couple of drops of glacial acetic acid have been added, and again washed in distilled water. Differentiation is effected by means of alcohol, the process being controlled under the microscope, and after clearing in xylol the specimen is mounted in Canada balsam.

As to Nissl's special method, I have never found it necessary to use an alkaline soap as a mordant, nor do I think that the other troublesome technicalities with which the method is burdened exert any appreciable influence on the precision of the results, and I would rather lay emphasis on care and experience in carrying out the ordinary details of the methods above enumerated. In addition to cytological methods, those of Golgi and Marchi were employed. Their details are well known, and need not be further described.

I "Untersuchungen über den Bau der Nervenzellen," Würzburg, 1898.

${ }^{2}$ Arch. f. Anat. u. Entwocklngsgesch., Leipzig, 1895, S. 396 ; ibid., 1897, S. 204, and Suppl. S. 273. 


\section{Results, Appearances in Healthy Cord.}

In considering the results of experiments on the action of a given toxine, one must always remember, as has already been stated, that the limits of variation compatible with health must be determined before concluding that the changes which may be seen really result from the poison employed. In view of this, it was necessary to determine the limits of variation which are found in the spinal cord of apparently healthy rabbits; and it also soon became obvious that as death not unfrequently occurred through the night or at times when the laboratory was closed, a preliminary study of the postmortem changes, likely to occur under the precise conditions of the main group of experiments, was indicated. The normal variation was determined by the examination of the spinal cords of seven healthy rabbits, and the series thus obtained showed that the motor cells found in the anterior cornua have, when in health, a characteristic and well-defined appearance (Plate XVII. Fig. 1).

The chromatic substance stains sharply, and is disposed in oblong or spindle-shaped masses, tending to run parallel to the boundaries of the cell, and entering all the protoplasmic processes, but being absent in the axis-cylinder process and immediately adjacent portion of the cell body. The chromatic masses have well-defined boundaries, which do not present an eroded aspect, and the granular structure of Nissl's bodies is usually invisible, or at least indistinct, except under high magnification, and in the case of very thin sections. The achromatic substance, when stained by erythrosin, fails to show any very definite structure, even under bigh magnification.

The nucleus contains but little basichromatin, and is best demonstrated by an acid stain such as erythrosin, when the structural arrangements become distinct. The nucleus, as a rule, contains one nucleolus, but in some instances two or more are visible. In addition to the nucleoli, some small masses of chromatin are occasionally visible within the nucleus. The nuclear membrane is of ten scarcely visible in the normal cell, but quite evident when morbid processes have induced chromatolysis. The size of the anterior cornual cells varies in the rabbit within somewhat wide limits. As observed by myself in a number of instances, they ranged between 40 and $100 \mu$ in their greatest length, the majority of them lying between 60 and $80 \mu$. Chromatophilia was rarely visible in any cells from normal spinal cords, provided fixation had been satisfactory; and in my later work I was able to obtain good fixation in almost every instance.

In addition to furnishing a series of standards with which to compare morbid cells, the "normal" series was also very useful, as affording a criterion for the ordinary size and appearance of the blood vessels of the cord. 


\section{Post-Mortem Changes.}

The specimens prepared to demonstrate post-mortem changes are, in my opinion, of considerable importance. Under this head, three groups of experiments were conducted. In the first group, which was the most important for the purposes of my subsequent research, six healthy rabbits were killed and left in their cages at the ordinary temperature of the animal house, which is moderately walmed by hot pipes, for six, twelve, eighteen, twenty, twenty-four, and thirty hours respectively. Portions from the lumbar and cervical regions of the spinal cord, from the brain, and from the peripheral nerves, were then dissected out, fixed by mercuric chloride, and stained by several of the various methods already enumerated. No changes of any importance could be detected in the first four specimens. In the fifth specimen, however,-in which death had occurred twenty-four hours before fixation,- - very notable alterations had manifested themselves. The achromatic substance tended to stain faintly, Nissl's bodies were slightly swollen, irregular, rather more granular than usual, and instead of their margins appearing sharp they presented an eroded aspect, whilst in many cells large clear vacuoles were distinctly visible. Since the first distinct alteration only occurs about twentyfour hours from the time of death, one may conclude that in all probability animals which have died through the night may safely be used on the following morning (Plate XVII. Fig. 2).

In the second group, portions of the spinal cord were removed, placed in normal saline solution, and kept either in ice or at the temperature of the room for varying periods. A test specimen was also prepared, which showed that immediately after death the normal appearances of the spinal cord were present in this instance. Of the series placed in normal saline and kept in ice, a specimen which remained for one hour before fixation showed no distinct change; another, which was left for two hours, exhibited slight granular disintegration of Nissl's bodies in a few of the cells; a specimen which was left for four hours showed moderate granular disintegration of Nissl's bodies and very slight commencing vacuolation; a specimen which was left for eight hours showed the same type of disintegration, and in addition more marked vacuolation. A specimen which had remained twenty-four hours before fixation showed advanced chromatolysis (the granular disintegration having progressed to a very marked degree), pronounced vacuolation, and, apparently, disappearance of some of the cells. The specimens which were left in normal saliue at the temperature of the room showed similar changes, but the alterations progressed somewhat more rapidly.

The third series of experiments was conducted on a rabbit which after death was placed in ice for twelve hours, after which the lumbar portion of the spinal cord was removed, with as little disturbance as

29 - .. OF PATI, - vor, v1. 
possible of the upper part of the vertebral canal. After twentyfour hours the cervical portion of the spinal cord was removed. In the first specimen no distinct change could be detected; in the second, granular degeneration was seen in some of the cells, though the condition was only slightly marked: the achromatic reticulum showed a slight tendency to take on the stain, but the unformed achromatic substance remained perfectly clear; no vacuolation was present. From this experiment it was obvious that any attempt to treat the spinal cord outside the body, before fixation, was liable to be fraught with the production of serious artefacts which would confuse the issues of the experiment. It also emerged that the appearance of post-mortem changes was infuenced to a certain degree by the temperature at which the spinal cord was kept, changes occurring in it more rapidly at higher temperatures, and being retarded when the temperature was near the freezing point.

\section{Diphtheritic Paralysis.}

My experiments on diphtheritic paralysis and subjects immediately related to it fall into seven groups:-

1. In the first of these, four rabbits were injected subcutaneously with four emulsions of diphtheria bacilli of varying degrees of virulence. Three survived, and manifested no symptoms whatever. The fourth died in ten days, symptoms only occurring within a day of the fatal issue. No nerve lesion was observed before death, and the spinal cord was free from any marked morbid appearance.

$$
\text { (DA, DB, Dc, Do.) }
$$

2. In the second group, which includes two series of injections, doses of toxine considerably below the lethal dose were given at intervals of several days. It was found that tolerance was established, so that eventually a large dose could be borne. In these cases no paralytic phenomena were discovered during life, whilst after death no pathological change was detected in the cells or other structures of the spinal cord.

$$
\text { (D2, D3.) }
$$

3. In the third group the rabbits received one or two large doses of toxine. Death resulted in four cases in one day, in five more within two days, three cases died on the third day, three on the fourth, one on the sixth, one on the seventh, and one during the second week. One case survived altogether, and several other cases are not included in the record because of circumstances which vitiated the experiment. In this group none of the rabbits dying within the first three days exhibited any paralytic phenomena, unless perhaps in the case of D33 and D10. Two at least of the three cases dying on the fourth day were observed to have a very slight degree of weakness 
of the limbs on that day, but I feel uncertain whether this was anything more than the natural weakness which precedes death. One rabbit which died at night during the second week was not observed to suffer from any weakness of the hind-limbs when the laboratory was closed on the previous evening. Beyoud a slight swelling of Nissl's bodies in some of the above cases, which might be rather due to the general effects of the disease on the animal than to any special local influence which the poison exerted on the nerve cells, the microscope generally revealed little or no change in the spinal cord. In some instances, however, a few of the anterior cornual cells, especially those belonging to the commissural groups, showed some fading of the chromatic substance. This condition is occasionally seen in spinal cords removed from normal rabbits, but in the latter case $I$ have never observed it occur to the same extent. In some of the later experiments the cells have also been examined by Golgi's method, but this process revealed no abnormality.

$$
\begin{gathered}
(\mathrm{D} 26, \mathrm{D} 27, \mathrm{D} 33, \mathrm{D} 38 ; \mathrm{D} 7, \mathrm{D} 28, \mathrm{D} 34, \mathrm{D} 35, \mathrm{D} 37 ; \mathrm{D} 8 \mathrm{~A}, \mathrm{D} 5, \mathrm{D} 10 ; \\
\mathrm{D} 9, \mathrm{D} 8 \mathrm{~B}, \mathrm{D} 15 ; \mathrm{D} 4 ; \mathrm{D} 6 ; \mathrm{DI} ; \mathrm{D} 25 .)
\end{gathered}
$$

4. The fourth group includes those cases where the toxine was administered according to the principle of subacute maximal intoxication. So far this method has been adopted in three cases. The rabbits developed paralytic symptoms ratber suddenly about the close of the first week, and died soon after the paralysis had become well marked. The affection was most distinctly marked in the hind-limbs; curiously enough the right side was more affected than the left in each case. ${ }^{1}$

An examination of the spinal cord yielded the following appearances:--

(a) Grey matter.-Many of the cells in the anterior cornual group were abnormal, and presented two types of morbid alteration. Some cells were slightly swollen, Nissl's bodies presented the appearauce of somewhat advanced disintegration, the achromatic substance stained but faintly with erythrosin, the nueleus and nucleolus appeared to be normal, and the nuclear membrane which, owing to the disappearance of much of the chromatic substance of the cell body was often unusually conspicuous, was not crumpled. Some cells, on the other hand, were altered in a very peculiar manner. They were markedly shrunken. Nissl's bodies were not very much affected at first sight; but, considering the reduced volume of the cell, the amount of chromatic substance which it contained was probably diminished; the achromatic substance took on the stain with unusual intensity, whilst many of this group of cells exhibited vacuolation of the protoplasm in a most marked degree (Plate XVII. Figs. 3, 4, and 5).

\footnotetext{
1 The injections were made subcutaneously in the lower dorsal and upper lumbar regions, or the right and left sides alternately.
} 
I have been unable as yet to prepare specimens of these cells treated by Golgi's method, as sufficient time has not yet elapsed for their preparation.

(b) White matter. - Marchi's method, so far as I have applied it, has revealed no degeneration in the white columns of the cord.

(c) Vascular changes. - In all these cases the capillaries have appeared to be dilated. In one at least of them actual hrmorrhage has occurred into the substance of the spinal cord.

$$
\text { (D42, D43, D45.) }
$$

5. In the fifth group will be found cases where both diphtheria toxine and diphtheria antitoxine have been administered. This series of experiments is still incomplete, but so far the facts which $I$ have observed have been-

(a) In three cases where the antitoxine was insufficient in strength to protect the rabbits from the full influence of a large dose of the toxine, death occurred within twenty-four hours without any paralytic symptoms. Microseopic examination of the spinal cord failed in these cases to disclose any abnormality.

(b) In one case where, after the administration of antitoxine in sufficient quantity to protect the animal, the latter was killed twentyfour hours after the injection. No symptoms occurred during life, nor was any change detected in the spinal cord.

(c) In two cases in which, under similar conditions, the rabbits were killed forty-eight hours after injection, no symptoms had appeared during life, nor was any morbid appearance detected in the spinal cord after death.

Further experiments are at present being conducted, in which one or several doses of toxine, along with a sufficient amount of antitoxine to prevent its lethal action, are administered, with the view of ascertaining whether paralysis may supervene at a later period. The observations are not sufficiently advanced as yet to permit of any report being submitted.

$$
\text { (D29, D30, D31, D32, D36, and D39.) }
$$

6. Only one experiment has yet been made in the sixth group. In view of Murawjeff's assertion that paralytic changes, almost identical with those produced by diphtheria toxine, may result from the employment of antitoxine, I have arranged for a series of cases in which large doses of the latter may be administered. In the one case which I can record, a rabbit received 1350 units of Behring's antitoxine within four days during last March, and in April the same rabbit received within a week as much as 6000 units of Burroughs, Wellcome, \& Co.'s antitoxic serum. It is still in perfect health, no abnormal consequences whatever having been observed. 
7. The seventh group has been devised to investigate the accuracy of Uhlenhuth and Moxter's statement regarding paralysia following the injection of ordinary serum. For this purpose I have injected a rabbit on five occasions within a week with from 20 to 30 c.c. of blood serum obtained from the slaughter-house, taking the precaution to render it sterile by filtration through a Pasteur-Chamberland bougie. Beyond some slight acceleration of the rate of breathing during and for a short time after the injection, absolutely no symptoms have occurred. The quantity of serum used being vastly in excess of that of the fluid employed in the toxine and antitoxine experiments, one may assume that the phenomena observed in these did not result from any action of the serum itself, apart from the influence of the toxic or antitoxic elements which it contained.

With regard to Uhlenhuth and Moxter's experiments, one cannot help thinking that the paralysis must either have resulted from general changes of vascular origin, caused by an extravagantly large addition to the fluid circulating in the blood vessels independently of the nature of the added fluid, or else to the presence of septic organisms and their products in the serums which those observers employed.

On Murawjeff's antitoxine observations I do not yet feel justified in expressing any decided opinion. My own limited observations have so far failed to confirm his statements, whilst the clinical opinion, that since antitoxine treatment has been introduced paralysis has become commoner, ${ }^{1}$ is obviously open to other interpretations than that which Murawjeff would suggest. It is, however, probable that, in cases of diphtheria, death may be warded off by the displacement of combined epitoxoids in the antidiphtheritic serum, by free diphtheria toxine from the patient's blood, and the epitoxoid so liberated, though less dangerous to life, may still be able to set up changes in the nerve structures, and so may induce paralysis. It is even conceivable that substances may exist in the blood of persons who are not suffering from diphtheria at all, which possess power to liberate some at least of these epitoxoids from their combination, and thus, indirectly, antitoxine might cause paralysis. This, however, is for the present, matter of pure speculation.

In the foregoing experiments I have repeatedly attempted to ascertain whether changes in the fibrillary structures of the nerve cells also occurred in consequence of the action of the toxines. So far, however, although various methods were attempted for their demonstration, I have been unable to see these fibrils, most likely because the motor cells of the rabbit's spinal cord are not favourable for this research.

${ }^{1}$ Cf. Lewin, "Nebenwirkungen der Arzneimittel," 3te Aufl. S. 398. 
I also had an opportunity a few months ago, at the Royal Hospital for Sick Children, of studying a case of post-diphtheritic paralysis, which was under the care of Dr. Playfair, and, as the case terminated fatally, I was able to examine the cells of the spinal cord also. This case has been fully reported by us elsewhere, ${ }^{1}$ but I may here state that we found vacuolation and early chromatolysis in some of the motor cells of the anterior cornua.

\section{RÉsumé.}

In conclusion, I may sum up the facts which I think may be asserted with regard to diphtheritic paralysis. Diphtheritic paralysis is associated not only with changes in the peripheral nerves, but also with alterations in the spinal cord itself. In my experiments, such changes were invariably present after death, when paralysis was observed during life. Of the latter, cellular changes are the most characteristic. They may, however, be associated with vascular ones. The changes are very definite and consist in chromatolysis to a moderate degree, in increased staining capacity of the achromatic substance for acid stains, and vacuolation of the cell protoplasm. In this connection I am inclined to support Nissl's opinion, that each toxic substance has a somewhat specific action on the nerve cells, and whilst it is probably impossible to tabulate the effects produced in such a way that one could definitely argue back from them to the toxine which caused them, still, there are more or less marked divergences in the action of different groups of toxic agents. Certainly, with each of the three toxic substances on which I have had an opportunity of making observations, lead, tetanus toxine and diphtheria toxine, the aspect of the affected cells differs in several particulars.

In diphtheritic paralysis the cell change is probably antecedent to the nerve change in the majority of cases. This, however, requires further investigation, before it can be asserted with confidence.

\section{RECORDS OF EXPERIMENTS.}

\section{Injection of Cultures of Diphtheria.}

RABBIT No. DA.-Culture of very slight virulence.

Nov. 8, 1895 . . Inoculated with above culture; no symptoms; rabbit survived.

$\mathrm{R}_{\mathrm{ABBIT}}$ No. DB.-Culture of slight virulence.

Nov. 8, 1895 . . Inoculated with above culture; no symptoms; rabbit survived.

RABBit No. Dc.-Culture of moderate virulence.

Nov. 8, 1895. . Inoculated with above culture; no symptoms; rabbit survived.

${ }^{1}$ Edin. Hosp. Rep., 1900, vol. vi. 
RABBIT No. DD.-Culture of decided rirulence.

Nov. 8,1895 . . Inoculated with above culture.

"18, " . . Rabbit died. Before death it exhibited no paralysis. No alteration was observed in the spinal cord.

\section{Injection of Diphtheria Toxine.}

RABBIT No. D2.-Weight, 1700 grms.-Toxine No. 1.

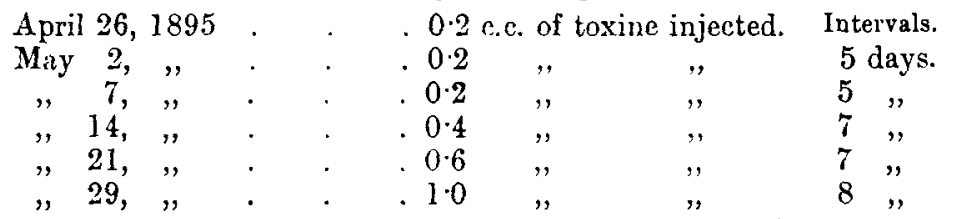

Animals showed no symptoms and became more or less immune. Weight risen to $2150 \mathrm{grms}$.

Rabbit No. D3.-Weight, 1500 grms.-Toxine No. 1.

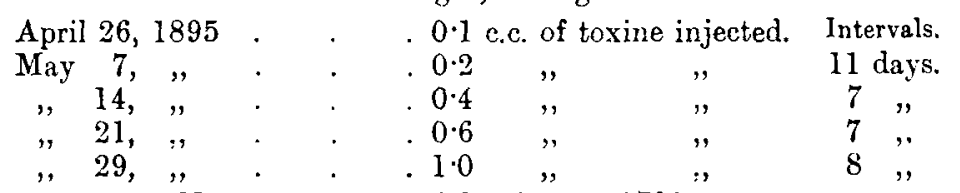

Yo symptoms; weight risen to $1700 \mathrm{grms}$.

RABBIT No. D5.-Weight, 1850 grms.-Toxine No. 2.

Dec. $17,1895 \quad$. $\quad .0 .75$ c.c. of toxine injected.

"20, ". . Rabbit found dead in morning; no symptoms on previous evening; no abnormality in spinal cord.

RABBIT No. D7.-Weight, $2450 \mathrm{grms}$.-Toxine No. 2.

Dec. 17,1895 . . 1.5 c.c. of toxine injected.

"19, , . . Died at midday; no paralysis; no abuormality in spinal cord.

Rabit No. D8A.-Weight, 1850 grms. - Toxine No. 2.

Dec. 17,1895 . . 10 c.c. of toxine injected.

"20, ". . Died at mid-day; no paralysis; no abnormality in spinal cord.

Rabit No. D4.-Weight, 3170 grms.-Toxine No. 2.

Jan. 16, $1896 \quad$. $\quad 0.75$ of toxine injected.

"22, ". . Died suddenly; no paralysis; spinal cord, normal.

RABBIT No. D6.-Weight, 2800 grms.-Toxine No. 2.

Jan. $16,1896 \quad$. $\quad 0.5$ c.c. of toxine injected.

" 23, ". . Died; no paralysis ; spinal cord, normal.

Rabbit No. D1.-Weight, 2010 grms.-Toxine No. 2.

Jan. $16,1896 \quad$. $\quad 0.3$ c.c. of toxine injected.

$" 28, "$. Found dead ; not exanined post-mortem.

RAввIT No. D9.-Weight, 2020 grms. - Toxine No. 3.

May $31,1897 \quad$. 1.0 c.c. of toxine injected.

June 4, ". . Died; very slight weakness noted in the hind-limbs for a few hours before death; spinal cord, normal. 
RABBIT No. D8B.-Weight, 2010 grms.-Toxine No. 3.

May 31,1897 . 1.0 c.c. of toxine injected.

June 4, . . Died ; slight weakness in hind-limbs for a few hours before death ; spinal cord, normal.

RabBIT No. D10.—Weight, 2070 grms.-Toxine No. 3.

June 21, 1897 . . 0.6 c.c. of toxine injected.

"24, ". . Died during night; very slight weakness observed previous evening.

RabBit No. D15.-Weight, 1850 grms.-Toxine No. 4.

Oct. $6,1897 \quad$. $\quad .0 \cdot 1$ c.c. of toxine injected.

$" 10, "$. . . Died during night; perhaps slight weakness present previous evening.

RABBit No. D25.-Weight, 2160 grms. - Toxine No. 5.

June, $2,1898 \quad$. $\quad 0.3$ c.c. of toxine injected. No symptoms; spinal cord normal.

RABBIT No. D26.-Weight, 1742 grms.-Toxine No. 6.

Sept. 6,1898 . . 0.6 c.c. of toxine injected.

"7, ". . . Died ; no paralysis ; spinal cord, slight chromatolysis.

RabBit No. D27.-Weight, 1625 grms.-Toxine No. 6.

Sept. $6,1898 \quad$. $\quad .03$ c.c. of toxine injected.

"7, , . . Died ; no paralysis ; spinal cord normal.

RabBit No. D28.-Weight, 1865 grms.-Toxine No 7.

Sept. $8,1898 \quad$. $\quad 0.4$ c.c. of toxine injected.

$" 10,, \quad$. . Found dead in morning; no paralysis on previous evening; spinal cord slightly affected.

RABBIT No. D33.-W Weight, 1235 grms. - Toxine No. 7 .

Sept. $27,1898 \quad$. $\quad 0.5$ c.c. of toxine injected.

$" 28, " \quad$. . Died; slight weakness of limbs shortly before death; spinal cord normal.

RABbIT No. D34.-Weight, 2135 grms.-Toxine No. 7.

Nov. $21,1898 \quad$. $\quad 0.5$ c.c. of toxine injected.

"23, ". . Found dead in morning; no weakness on previous evening; spinal cord, some cells slight chromatolysis.

RABBIT No. D35.-Weight, 2230 grms.-Toxine No. 7.

Nov. $21,1898 \quad$. $\quad 0.5$ c.c. of toxine injected.

$, 23, "$. . Found dead in morning; no weakness on previous evening; very slight chromatolysis.

RABBit No. D37.-Weight, 2280 grms.-Toxine No. 7.

Dec. $29,1898 \quad$. $\quad 0.5$ c.c. of toxine injected.

"31, ". . . Died; no paralysis ; spinal cord, slight changes.

RABBIT No. D38.-Weight, 1760 grms.-Toxine No. 7.

Dec. $29,1898 \quad$. $\quad 0.5$ c.c. of toxine injected.

"30, ". . . Died; no paralysis; spinal cord, very slight chromatolysis. 
Rabbit No. D42.-Weight, 1450 grms.-Toxine No. 7 .

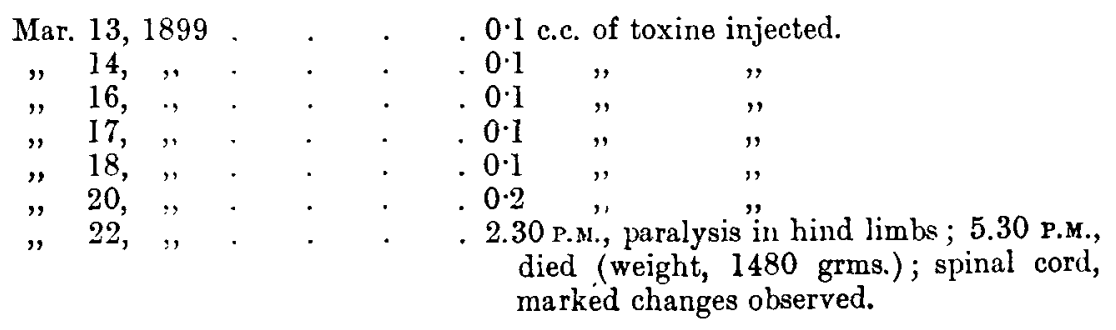

RABBit No. D43.- Weight, 1600 grms.-Toxine No. T.

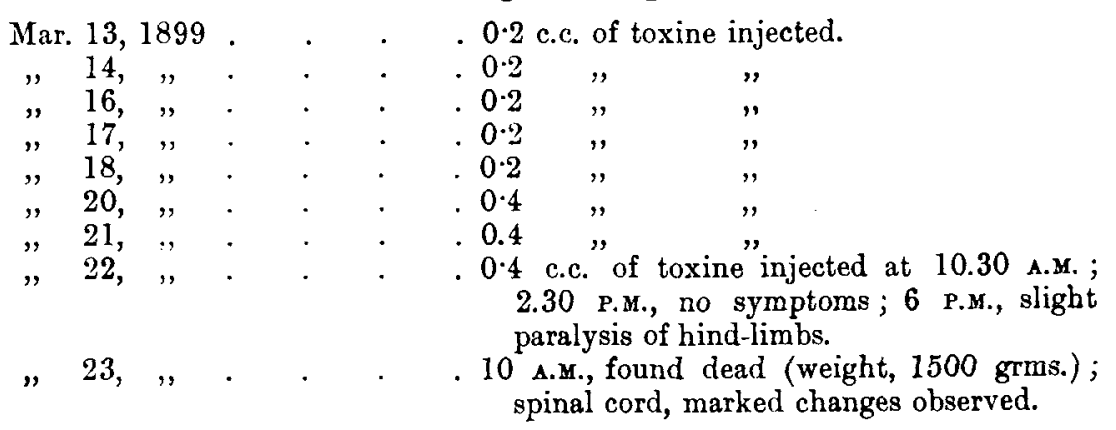

RABbit No. D45.-Weight, 1570 grms.-Toxine No. 7 .

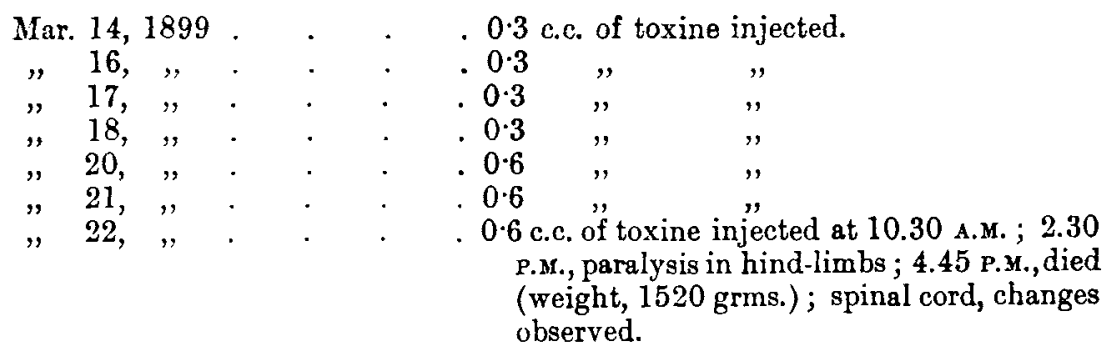

Index to Toxines employed.

\begin{tabular}{|c|c|c|c|c|c|c|c|c|}
\hline No. & Source. & \multicolumn{7}{|c|}{ Toxicity } \\
\hline 1 & R.C.P.Ed. Laboratory & 0.2 & $\mathrm{k}$ & ne & 580 & ms. & a eight & days. \\
\hline 2 & ", & 0.5 & , & ", & 540 & , & three & ", \\
\hline 3 & ", & $0 \cdot 4$ & $"$ & ", & 500 & $"$ & two & $"$, \\
\hline 4 & ", & 0.5 & ", & ," & 500 & $"$ & four & $"$ \\
\hline 5 & " & 0.2 & " & " & 560 & , & three & $n$ \\
\hline 6 & , & 0.2 & " & " & 560 & ", & three & "' \\
\hline 7 & \multicolumn{8}{|c|}{ Messrs Burroughs, Wellcome, \& Co., undetermined toxicity. } \\
\hline
\end{tabular}

The last of these (No. 73) was much the best toxine, and appeared perfectly transparent, straw-coloured, and free from all sediment. 


\section{Injection of Toxine and Antitoxine.}

RABBIT No. D29.-Weight, 2295 grms.-Toxine No. 7.

Sept. 15, 1898 . $\quad 0.6$ c.c. of toxine injected at 11 A.M. ; 1.0 c.c. antitoxine previously prepared in laboratory of Royal College of Physicians, Edin., injected at 2 P.M. The rabbit survived until 20th September, when it was killed; no symptoms; spinal cord, normal.

RabBit No. D30.-Weight, 2085 grms.-Toxine No. 7.

Sept. 15,1898 . $\quad 0.6$ c.c toxine at 11 A.x.; 1.6 c.c. antitoxine (as above) at 5.30 P.м.

„16, " . . Found dead in morning; spinal cord, normal.

RabBIT No. I)31.-Weight, 1872 grmis. -Toxine No. 7.

Sept. 27,1898 . . 0.5 c.c. toxine at 10.30 A.M. ; 1.0 c.c. antitoxine (as above) at 3 P.M. Survived; no symptoms. Killed in forty-eight hours; spinal cord, normal.

RABbiT No. D36.-Weight, 2190 grms.-Toxine No. 7 .

Dec. 29,1898 . $\quad 0.5$ c.c. toxine at 11.30 A.M. ; 60 units Behring's antitoxine at the same hour.

, 30, , . . . Died in morning, about twenty-one hours after injection; no paralysis; spinal cord, normal.

KabBit No. D39.-Weight, 2120 grms.-Toxine No. 7.

Dec. $29,1898 \quad . \quad 0.5$ c.c. toxine at 11.30 A.M. ; 30 units Behring's antitoxine at 3 P.M.

" 30. ". . . Died in twenty hours after injection; no paralysis; spinal cord, slight chromatolysis.

\section{Antitoxine Alone.}

RABbit No. D44.—Weight, 1650 grms.

Mar. 14, 1899 . . . . . 500 units Behring's antitoxine.

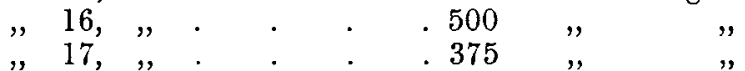

$" 17, "$. No symptoms ; weight, 1640 grms."

April 8, , . . . . 1500 units Burroughs \& Wellcome's antitoxine, series 79 .

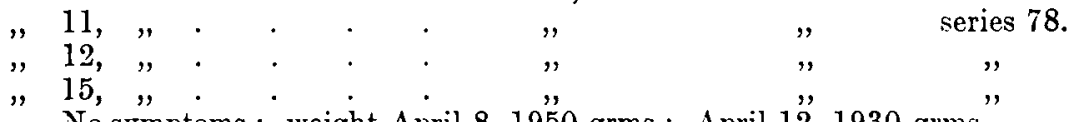

\section{Blood Serum.}

Rabbit No. D47.-Weight, 1950 grms.

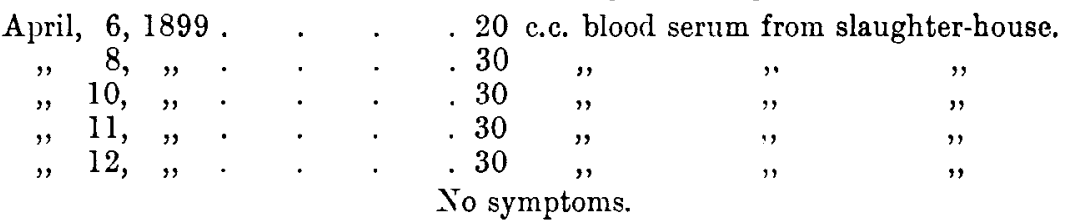




\section{BIBLIOGRAPHY.}

\section{Post-Mortem Changes.}

Schulz, R.,

Barbacci e Campacci, ColucCI

França, Carlos,

NEPPI, .

Pasquale, S.,

EWing, James,

Levi, G.,

GULL, SiR W.,

Charcot et Vulpian,

WEBER, H.,

BuHL, L., . . . .

Cros,

Lorain et Lépine,

Liouville

Oertel

BaILty,

MAIER, R.

SchweItZER, H.,

LEYDEN,

Roger et Damaschino,

RATHERY

Pierret,

VulPIAN,

RUMPF, ,

SANNE,

HARDY,

Déterine,

SсHЕсн

DEJERINE ET BARTH,

LANDOUZY,

Quinquand,
Neurol. Centralbr., Leipzig, 1883, Bd. ii. S. 529.

Riv. di patol. nerv. e ment., 1897, tômo ii. p. 337.

Ann. di Nevrol., 1897, tome (?), p. 12.

Arch de Med., Madrid, 1898, tome ii. p. 1.

Riv. di patol. nerv., Firenze, 1897, tômo ii. p. 152.

Sperimentale, Firenze, 1897, tômo li. No. l.

Arch. Neurol. and Psycho-Path., Utica, 1898, vol. i. p. 263 (good bibliography).

Riv. di patol. nerv., Firenze, 1898, tômo iii. No. 1.

\section{Dipetherin.}

Lancet, London, 1858, vol. iì. p. 4.

Compt. rend. Soc. de biol., Paris, 1862, Súr. 3, tome iv. p. 173.

'Virchou's Archiv, 1864, Bd. xxiii. S. 115.

Ztschr. f. Biol, 1867, Bd. iii. S. 341.

"Essai sur les paralysies diphthéritiques," Thèse, Paris, 1868.

"Nouveau dict. de méd. et de chir. prat." Paris, 1869 (article).

Bull. Soc. anat. de Paris, 1865, tome xl. p. 579.

Deutsches Arch. f. Klin. Med., Leipzig. 18i1, Bd. viii. S. 242.

Gaz. d. Thop., Paris, 1872, No. 12, p. 93.

(Quoted by P. Meyer, q.v.), 1870.

Ber. l. naturf, Gesellsch. zu Freib. i. Br., 1870.

Ztsclir, f. klin. Med., Berlin, 1880, Bd. i. S. 1 and 387 .

"Traité de méd. de Charcot et Bouchard," Paris, $18 \pi 5$, tome iii. p. 192.

"Des accidents de la convalescence," etc., Thèse, Paris, 1875.

Compt. rend. Soc. de biol., Paris, 1876, Sír. 6, tome iii. p. 403.

"Leçons sur les maladies du système nerveux," Paris, 1876.

Deutsches Arch. f. klin. Med., Leipzig, 1877, Bd. xx. S. 120.

"Traité de la diphthérie," Paris, 187T.

Ann. d. mal. de l'ureille du larynx, etc., Paris, 1878 , tome iv. p. 125.

Arch. de physiol. norm. et path., Paris, 1876, tome viii. p. 317.

Ihid., 1878, tome x. p. 107.

Deutsches Arch. f. klin. Med., Leipzig, 1879, Bd. xxiii. S. 152.

Arch. de physiol. norm. et path., Paris, 1880, tome xii. p. 673.

"Des paralysies dans les maladies aigues," Thèse, Paris, 1880.

“Traité de chimie pathol.," Paris, 1880. 
SAINCLAIR,

Abercrombie,

GAUCHER,

Meyer, Paul,

KIDD,

SANNE,

Mendel,
"Contribution à l'étude de la pathogenie des paralysies diphthériques," Thèse, Lyon, 1880.

Trans. Internat. Med. Cong., London, 1881, vol. iv. p. 61.

Journ. de l'anat. et physiol., etc., Paris, 1881, tome xvii. p. 17.

Virchow's Archiv, 1881, Bd. lxxxv. S. 181 (good bibliography).

Med. Chir. Trans., London, 1883, vol. lxvi. p. 133.

"Dict. encyclop. d. sciences médicales," etc., Paris, 1884, tome xxi. p. 589 (art. "Diphthérie").

Neurol. Centralbl., Leipzig, 1885, Bd. iv. S. 128.

Berl. klin. Wchnschr, 1885, Bd. xxii. S. 190.

"Harveian Lectures," London, 1886, p. 108.

Brit. Med. Journ., London, 1888, vol. i. p. 225.

"Augenheilkunde," Leipzig u. Wien, 1889, S. 721.

Boston Med. and S. Journ., 1889, vol. cxx. p. 581.

"Disease in Children," 2nd edition, London, 1889, p. 98.

Haltager, . . . . . Hosp.-Tid., Kjöbenhavn, 1890.

Babinsk I, . . . . . . Gaz. hebd. de. méd., Paris, 1890, p. 374.

Pat, . . . . . . . "Ueber Multiple Neuritis," Wien, 1891.

Déjerine, . . . . . . "Traité de méd. de Charcot et Bouchard," Paris, 1892 , tome iii. p. 193.

Arnheim, . . . . . . Ibid., tome iii. p. 193.

McBride, . . . . " Diseases of the Throat, Nose, and Ear," Edinburgh and London, 1892, p. 20.

Osler, . . . . . . "Principles and Practice of Medicine," Edinburgh and London, 1892, p. 106.

Prersz, . . . . . . . Deutzche Ztschr. f. Nervenh., Leipzig, 1892, Bd. vi. S. 95.

GAY, . . . . . . . Brain, London, 1893, vol. xvi. p. 431.

Ross and Judson Bury, . "On Peripheral Neuritis," London, 1893.

Stcherbak, . . . . . Rev. neurol., Paris, 1893, tome i. p. 143.

Bikeles, . . . . . . Arb. a. d. Inst. f. Anat. u. Physiol. d. Centralnervensyst. an $d$. Wien. Univ., Leipzig u. Wien, 1894, H. ii. S. 110.

Enriquez et Hallion,. . Rev. neurol., Paris, 1894, p. 282 ; and Compt. rend. Soc. de biol.. Paris, 1894, tome v. pp. 59

M'Intrre,"G. W., . . . . Northwest. Lancet, St. Paul, 1894, vol. xiv. p. 266.

Vincext, H., . . . . . Arch. de méd. expér. et d'anat. path., Paris, 1894, tome vi. p. 513.

CrocQ, J. (fils), . . . . Ibid., tome vii. p. 507.

Vidal et Bezançon, . . Ann. de l'Inst. Pasteur, Paris, 1895, tome ix.p. 104.

Pernici e Scagliosi, . . Pisani, Palermo, 1895, No. 2.

Babinski, . . . . . "Traité de méd. de Charcot et Bouchard," Paris, 1895, tome vi. p. 769 (article).

Counmont, Doyon, Ex Arch. de physiol. norm. et path., Paris, 1896, Paviot

Croce, J. (fils),

GEE,

KANTHACK, tome viii. p. 321 .

"Recherches expérimentales sur les altérations du système nerveux dans les paralysies diphthéritiques," Paris, 1896.

Allbutt's "System of Medicine," London, 1896, vol. i. (art. "Diphtheria"). 
Madsen,

"Experimentelle Untersogelser over Difterigiften," Copenhagen, 1896.

Maxicatide, M.,. . . . Rev. mens. d. mal. de l'enf., Paris, 1896, tome xiv. p. 465.

Dziergowski and Oxufro- Arch. de sc. biol., St. Pétersbourg, 1897, tome vi. wicz. p. 41.

Katz, O.,. . . . . . Arch. f. Kinderll., Stuttgart, 1897, Bd. xxiii. S. 68.

Murawjeff (Mouravieff), Arch. de méd. expér. et d'anat. path., Paris, 1897, tome ix. p. 1165.

Arch. russes de pathol., etc., St. Pétersbourg, 1897, tome vi. p. 161. Nicanoroff, I'., . . . . . Fortschr. d. Med., Berlin, 1897, Bd. xvi. S. 93. p. 57.

Sharp, Gorvon, . . . . Journ. Anat. and Physiol., London, 1897, vol. xxxi. p. 199.

BABEs, V.,. . . . . . Berl. klin. Wchnschr., 1898, Bd. xxxv. SS. 6, 36 , and 56 .

Berkley, H. J., . . . . Johns Hopkins Hosp. Bull., Baltimore, 1897, vol. viii. p. 23.

Donaggio, A., . . . . Riv. di patol. nerv., Firenze, 1898, tômo iii. No. 6.

Enriquez et Hallion,. . Compt. rend. Soc. de biol., Paris, 1898, tome v. p. 59.

Arch. de physiol. norm. et path., Paris, 1898, tome x. p. 393.

FÉrÉ, C., . . . . . Journ. de neurol. et hypnol., Paris, 1898, tome iii. p. 231 (Abstract).

Iuce, H., . . . . . . Deutsche Ztschr. f. Nervenk., Leipzig, 1898, Bd. xii. S. 385 .

Luisada e Pacchioni, . Gior. d. r. Accad. di med. di Torino, 1898 (Abstract); Policlin., Roma, 1898, tômo v. p. 362.

Mura fjeff, . . . . . Rev. neurol., Paris, 1898, tome vi. p. 426.

Spronck, C. H. H., . . . Nederl. Weekbl. v. Geneesk., Amsterdam, 1898, Jaar. xxxiv. p. 690.

Thомas, J. J., . . . . Boston Med. and S. Journ., 1898, vol. cxxxviii. pp. 76, 91, 123.

Woodhend, G. Sims, . . Brit. Med. Journ., London, 1898, vol. ii. p. 593.

Ziegler, . . . . . "Lehrbuch der Allg. Pathol." Jena, 1898, 9th Aufl. Bd. ii. S. 272, 275.

Bury, Judson, . . . . Allbutt's "System of Medicine," London, 1899, vol. vi. (article, "Peripheral Neuritis").

Bruckner, . . . . . Schmidt's Jahrb., Leipzig, 1899, Bd. cclxi. S. 27, 141.

Uhlenhuth y. Moxter, . Fortschr. d. Med., Berlin, 1898, Bd. xvi. S. 361.

III. On Diphtheria Toxine, etc.

Bernaeim, J., . . . . Arch. f. Hyg., München u. Leipzig, 1897, Bd. xxviii. S. 138.

Roux et Yersin, . . . Ann. de l'Inst. Pasteur, Paris, 1888, tome ii. p. 629 ; 1889 , tome iii. p. $273 ; 1890$, tome iv. p. 385 ; 1894 , tome viii. p. 612 .

GaUthier, A., . . . . "Les toxines," Paris, 1896, esp. pp. 551 to 562.

Brieger U. Fraenkel, . . Berl. klin. Wchnschr., 1890, 1891, 1892. 
Guinocher, . . . . Compt. rend. Soc. de biol., Paris, 1892, Sér. 9, tome iv. p. 40.

Blumenthal, F., . . . Deutsche med. Wchnschr., Leipzig, 1897, Bd. xxiii. S. 24.

AbBa, F., . . . . . . Riforma med., Roma, 1898, tômo xiv. p. 47.

Bomstern, . . . . . Centralbl. f. Bakteriol. u. Parasitenk., Jena, 1898, Bd. xxv. S. 963.

Ehrlich, PaUl, . . . . Deutsche med. Wchnschr., Leipzig, 1898, Bd. xxiv. S. 38.

"Die Werthbemessung des Diphtherieheilserum, u. deren theoret. Grundlagen," Jena, 1897.

Fornaca, L., . . . . . Riforma med., Roma, 1898, tômo xiv. p. 245.

Martin, L., . . . . . Ann. de l'Inst. Pasteur, Paris, 1898, tome xii. p. 26.

Martin, Sidney, . . . Lancet, London, 1898, vol. i. pp. 1665, 1737 ; 1898 , vol. ii. pp. 1,71 .

Spronck, C. H. H., . . . Ann. de l'Inst. Pasteur, Paris, 1898, tome xii. p. 10.

Plimmer, . . . . . Journ. Path. and Bacteriol., Edin. and London, 1898, vol. v. p. 489.

Behrivg, E., . . . . . Deutsche med. Wchnschr., Leipzig, 1899, Bd. xxv. S. 1 .

\section{DESCRIPTION OF PLATE XVII.}

FIG. 1.-Normal stichochrome cell from anterior cornu of spinal cord of a rabbit. Stained with methylene-blue and erythrosin. Nissl's bodies sharply defined, nucleus contains two nucleoli (a condition not uncommonly found in healthy cells), nuclear reticulum sharply defined and taking on the erythrosin stain. Axiscylinder hillock free from Nissl's bodies. Page 444. $(\times 500$.

Fig. 2.-Post-mortem changes in stichochrome cells from anterior cornu of spinal cord of a rabbit ( $\frac{1}{2} \frac{1}{2}$ oil imm. obj.) For description, see page 445. ( $\left.\times 1000.\right)$

FIc. 3.-Diphtheritic paralysis. Nissl's bodies irregular and broken up. Vacuolation of protoplasm. Strong staining of nucleus and of achromatic substance of cell body by erythrosin. ( $x^{x}$ oil imm. obj.) Page 447. (x 900.)

Fig. 4.-Diphtheritic paralysis. Nissl's bodies irregular, granular, and absent at some parts of cell body. ( 12 oil imm. obj.) ( $x 900$.

FIG. 5. - Group of anterior cornual cells exhibiting changes found in diphtheritic paralysis, $(\times 300$. 


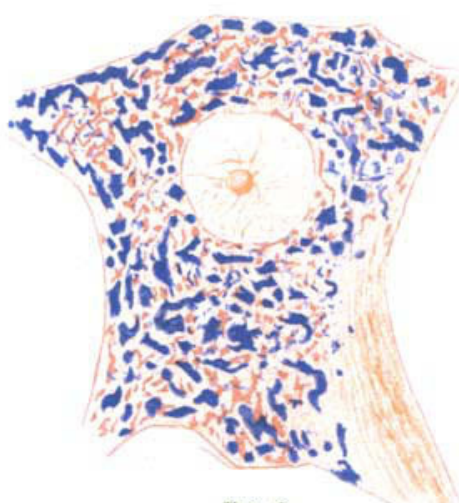

Fig. 4 .

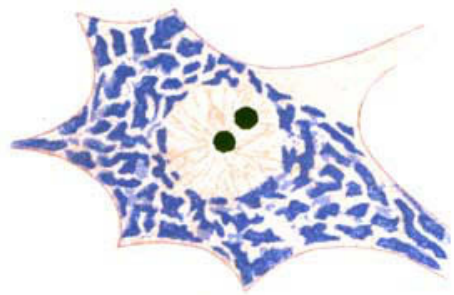

Fig 1
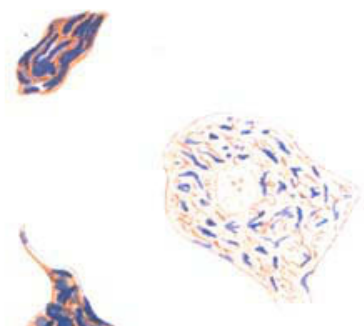

Fig 5
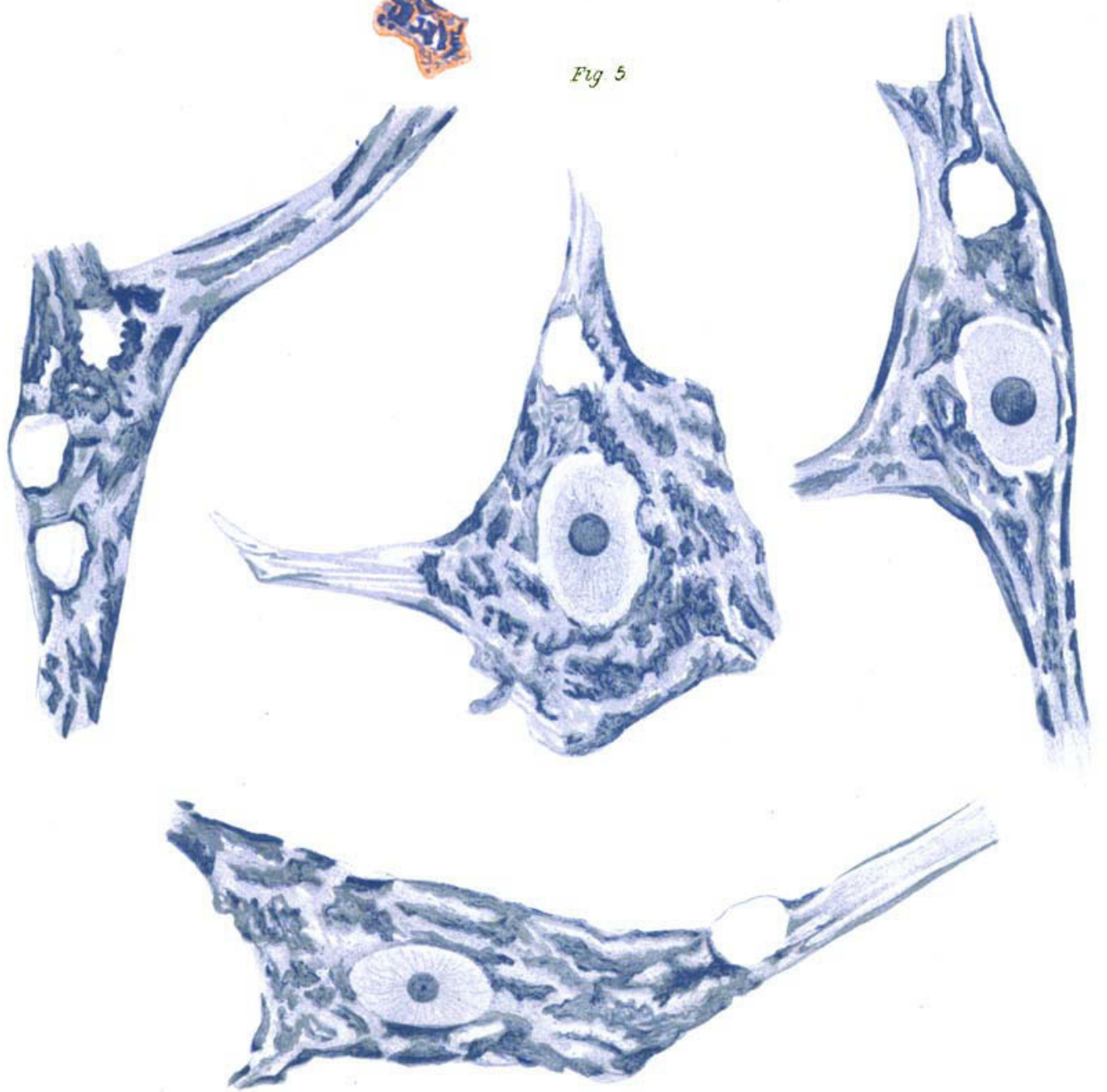

Fig. 2. 